\title{
Deconstructing the Psychoanalyst of Philosophy
}

\author{
Ali Zare'i \\ PhD Student of Philosophy, University of Isfahan \\ zarei_ali@yahoo.com \\ Yousef Shaghool \\ Associate Professor of Philosophy, University of Isfahan \\ y.shaghool@ltr.ui.ac.ir
}

\section{Doi:10.5901/mjss.2014.v5n23p1949}

\begin{abstract}
This paper tries to demonstrate how Jacques Derrida deconstructs Hegel's philosophy through detecting an abyss at the hub of the Hegelian system. Derrida's work on Hegel, Glas, which is concerned with Hegel's philosophy, highlights the remarkable resemblance between Hegel's dialectic and Freud's psychoanalysis. Derrida's argument draws a comparison between the Hegelian concept of Aufhebung and Freud's repression. This comparative study aims at showing that no systematic thinking or analysis can release itself from an indigestible and paradoxical element that constitutes the abyss of the systematic or analytical thinking. The first part of the article shows how Derrida, inspired by Kant, thinks of the abyss of the system as the quasi-transcendental that, in a paradoxical way, makes philosophical system both possible and impossible. Concentrating on the concept of repression, the second part delineates similarities of the dialectic and psychoanalysis. In Hegel's view, there is nothing out of cognition; however, Hegel's obsession with Antigone's tragedy reveals that there are dark sides remained outside of the Hegelian system. The last section deals with these remains in Hegel's account of Antigone. Such abyssal points assert that there is a sort of resistance to psychoanalysis, or the process of analysis in general, which deconstruction has always attempted to make us more sensitive to it.
\end{abstract}

Keywords: repression, dialectic, deconstruction, abyss, psychoanalysis, the quasi-transcendental, Hegel, Derrida

\section{Introduction}

Since deconstruction tries to reveal the unread sides of the text, some may conclude that deconstruction can be defined as the psychoanalysis of the text, but it should be noticed that although Jacques Derrida acknowledges Sigmund Freud's achievements, he is one of the serious critics of psychoanalysis, and the concept of analysis in general. Derrida has dealt with this subject in different works. The investigation of Freud's conception of repression, in Derrida's Glas, in connection with Hegelian dialectic, and the concept of Aufhebung in particular, can be helpful in clarifying his deconstructive position in this regard. G. W. F. Hegel faced the unresolved and repressed problems of philosophy as a psychoanalyst and that is why the resemblance between Aufhebung and repression deserves a critical scrutiny. Why Derrida criticizes both dialectic and psychoanalysis in spite of appreciating some of their insights and achievements? Both Hegel and Freud's thought can be characterized by their "analytical" inclinations. The analytical nature of philosophical and psychoanalytical discourses, which pursue a systematic thought and justifiable explanation for different phenomena, has made them entrapped by metaphysics of presence. This paper tries to demonstrate that deconstruction resists analysis or analytical discourses such as speculative philosophy or psychoanalysis. This resistance is originating from the analytical discourse itself. There is an indigestible point at the very hub of every analysis. In his reading of other text, Derrida was always interested in such obscure points. Our argument will begin with a discussion on Derrida's quasi-transcendentalism, which will give an overview of deconstructive treatment of philosophical problems that can distinguish it from its predecessors. Keeping in mind these deconstructive strategies, we will then try to provide a brief comparative study of the two key concepts in this article, repression and dialectic, by which we will emphasize similarities of Freudian psychoanalysis and Hegelian dialectical thinking in resolving repressed wishes.

It will be shown that although Derrida acknowledges the way Hegel and Freud dealt with the unintelligible and dark sides of mind and philosophy, including death drive and negativity, deconstruction diverges from philosophical and psychoanalytical discourse through resisting any sort of analysis by highlighting the abyss of the systematic and 
analytical thinking. Derrida thinks that there are elements at the very heart of the philosophical and psychoanalytical discourse that resist analysis; refractory elements that cannot be controlled by the system of thought and will never submit to analysis.

\section{The Quasi-Transcendental}

Kant's transcendental philosophy has been often compared to Hegel's immanent and concrete thinking. Derrida is a postKantian and a post-Hegelian thinker who believes in neither transcendence nor immanence. His approach is quasitranscendental because while Hegel's resemblance to Freud is central to Glas; Derrida thinks that "Kant tries to subtract his discourse from the psychoanalytic instance" (Derrida, 1986, p. 215). Accordingly, in his reading of Hegel, Derrida deploys some Kantian insights, particularly when he accentuates the resemblance of dialectic to psychoanalysis in Glas.

If we follow the trajectory of the concept of the transcendental from Kant to Derrida in a very brief overview, it will be observed that the starting point was the Kantian transcendental turn. Then Hegel criticized it within the framework of his immanent philosophy. Finally, a new formulation of transcendentalism appears in Heidegger's thought. Regarding the great impact of Heidegger on Derrida, deconstruction can be characterized as quasi-transcendental thinking. Reformulation of the transcendental approach paved the way for leveling a strong criticism at Hegel's dialectical thinking.

What is important in a transcendental thinking is moving from the present situation to the other position. Kant does not like to remain confined to the sensual experience and transcends to the other realm, which are independent of the experience, in order to show under what conditions the experience is going to be possible. These other things are the transcendental and a priori principles, which have been discovered by going beyond the usual limits of sensual experience. Moving beyond the usual limits is also important for Heidegger. According to Heidegger, human being's conception of death can be distinguished from that of animals and other creatures due to the openness of da-sein towards the world and his understanding of Being. When we become aware of being disclosed to the world and being toward death, we will transcend the limits of the ontic level and will be able to think of the meaning of Being which has been neglected by onto-theology. Of course, determining the transcendental principles of knowledge is not a Heideggerian concern; however, what is important for him is the very process or movement of transcendence not the determination of the transcendental principles of knowledge. In a similar way, Derrida is concerned with process of transcending to the other and not determining or defining what the other is. Deconstruction is a perpetual movement beyond the limits of metaphysical systems or institutions in order to highlight the significance of the non-system, the indigestible element of the system that appears as a foreigner, the other, which is always denied. In the question of Antigone, as it will be discussed in the last section of the article, the comprehensive system of speculative philosophy suffers from a gap. Therefore, Derrida is not a transcendentalist in a Kantian sense, but his thinking is operated in a quasi-transcendental plane. It is in a quasi-transcendental plane that Derrida can deconstruct Hegel; by referring to the other of Hegelian system, which remained unknown despite all Hegel's attempts in treatment of the repressed and forgotten points by means of cognition and thorough analysis.

Deploying this Kantian insight, Derrida directs a play in Glas that its actors are Hegel, Freud and Kant while Derrida himself transcends the scene of philosophy and psychoanalysis and tries to show how these remains or the abysses constitute the condition of possibility and impossibility of any system.

\section{The Psychoanalyst of Philosophy}

Freud thinks that repression is an inevitable part in the process of the formation of man's identity and the unconscious will always contain repressed elements. From the beginning of his career Freud has maintained that the striking point in formation of man's character or identity is that he has secrets that keeps from himself (Billig, 2004, p. 12). Mental illnesses have also their roots in theses simultaneously hidden and denied secrets. The question is how to face such dark sides of our character in order not to let them hurt us but channel the wild energy of them into productivity and creativity of life. The same as Freud, when Hegel starts his dialectical thinking with the destructive power of negation, he is going to face repressed sides of philosophy by bringing thing-in-itself or infinity under cognition.

Hegel's philosophy not only resembles Freudian thought in some significant aspects but also he has overtaken Freud by treating repression as ongoing process (Gearhart, 2001, p. 154). The self-deceit or willed-forgetting that constitutes repression can be traced in philosophy too. As a psychoanalyst treats dark sides of the mind, Hegel tries to treat the noumena or thing-in-itself; the most significant repressed issue in Kant's philosophy. Kant's representation theory would inevitably lead to the distinction between the intelligible domain of phenomena and the unintelligible domain of thing-in-itself, but for Hegel there is nothing out of cognition. For overcoming the problem of the thing-in-itself, Hegel 
has established a thoroughly new mode of thinking by recognizing "negation" as a part of philosophical system. Establishment of a negative philosophy enabled Hegel to face unresolved problems of modern philosophy and overcome existing gaps of Kantian system. Hegel thus tried to heal the wounds of philosophy as a psychoanalyst treats a patient.

Taking such a new path was accompanied with series of attacks on theories of representation and epistemological explanations that aimed at reducing the rate of errors in the process of formation of knowledge. The repression of unintelligible points and forgetting negativity has accumulated a large amount of energy that by facing the repressed problems it will be released and set a dialectical movement. In this way, Hegel is dealing with repression through his concept of Aufhebung that means to remove, keep and sublate simultaneously.

Moreover, both Hegel and Freud think within an inter-subjective framework. When Hegel replaces the previous knowledge theories with science of the experience of consciousness in which self-consciousness appears as desire until it gets satisfied in the other consciousness, he is highlighting the inter-subjectivity of the dialectical process. For Freud, too, the entire story of the psychoanalysis occurs in an inter-subjective context of family or society. Derrida shows throughout Glas that both Hegel and Freud are thinkers of family; whether the ordinary family (child-mother-father) or the divine family of Jesus, the Lord and Virgin Mary that can be traced in Hegel's obsession with Christianity.

Referring to the famous Freudian views shows that child's first encounter with the other is her/his encounter with mother. The baby is separated from mother's body as a part of a whole and the only way to stay calm is being as close as possible to the mother. However, it is impossible for mother to keep an everlasting connection with her child; the immediate relation can no longer be kept. The only absolute immediateness would be possible at the womb. At the womb, there was no distance between the child's needs and getting satisfied by attaining what he/she wished; the ideal conditions for a man to be steadily supplied with what he/she desires. After birth, such immediateness does no longer exist, but man's desire to resume the ideal condition of the womb life never ceases or vanishes completely; the desire for rejoining the womb life is repressed. Man's birth is a traumatic event by which he/she is passed from his ideal conditions to the world of dissatisfaction, breaks, gaps and repressions. After birth, no need or desire can be completely satisfied, so the question is how we should manage our needs and desires in order to reduce the tension of organism and avoid more pain.

The repression has double functions. On the one hand, it reduces the tension by forgetting the traumatic event while, on the other hand, it may fill the unconsciousness with what it has excluded from consciousness. The return of the repressed will cause neuroses (Fodor \& Gaynor, 1950, p. 158). Reducing the organism's tension and anxiety by expelling terrible thoughts and memories is inevitable in man's development. Sometimes, because of some serious deprivation, the way this mechanism works may collapse the natural process. Here, the psychological problems will emerge. Thus, the repression eradicates while preserves and sublimates the repressed memories. Such multifunctional mechanism reminds us of Hegel's Aufhebung, which will be examined later.

Remembering the terrible memories, which has been repressed, is central to the process of treatment or the analysis of the psyche. The psychoanalyst tries to persuade the patient to remember the terrible event that causes illnesses. Remembering is a painful operation, a surgery on the psyche, by which man will face dark sides of his character and this painful encounter will automatically enable him to manage the problem. The unintelligible points, which were concealed from the consciousness, become intelligible; the darkness turns into light and the wound will be healed in this way. However, it does not mean that the repressed elements will be removed thoroughly; they will still exist but the way the consciousness is going to deal with them has undergone a dramatic change. The process of repression is in progress again but with less mental pain.

As the psychoanalyst of philosophy, Hegel has realized that there are some fundamental issues that have been repressed over history of philosophy. Due to the destructive nature of problems such as negativity and death, facing the dark sides of philosophical thinking is actually unbearable and philosophers have preferred to repress them, although they have returned from time to time. The destructive force of negativity, for example, returned in Kant's analysis of the sublime as the sequence of the repression of thing-in-itself. Although Kant tried to account for this negative power within the framework of his transcendental philosophy, Hegel believes that the experience of the sublime is an evidence of the power of negation, which is in progress in the experience of the consciousness while transgresses existing forms and elevates to higher levels.

Since the child will learn that s/he cannot keep her/his unity with mother, s/he tries to experience the immediate unity with her by means of some other actions. Returning to the primary unity with mother becomes the main goal of man's life and all of his activities over life will be devoted to gaining satisfaction, which has been lost when man has been thrown into the world. It seems that the same process is happening in gaining knowledge. Gaining immediate knowledge is impossible and that is why, for Hegel, sense certainty, which appears as the richest sort of knowledge, "in fact yields the most abstract and the very poorest truth" (Hegel, 2010, p. 85). Moreover, the simple conception of the world in sense 
certainty is similar to child's narcissistic conception of the world. The child treats external world as primitive people who believed in animism and magic. Since, due to her/his narcissistic wishes, s/he thinks that world must be under her/his control s/he treats the external world as if the objects understand her/him and perform her/his orders. In this way, the child will deal with the question of unity and bridge the gap between him/herself and the world, which is primarily the gap between the child and mother. That is the case with sense certainty as the first stage of the encounter with the world.

What turns out from the preliminary steps of gaining knowledge of the external world in sense certainty is that the gap between man and the world, as the gap of mother-child, cannot be bridged. The man, or subject, is spilt; it should bear this gap all over its trajectory. Thus, the experience of consciousness, which develops through subject, starts with a gap that functions as the negation of stable form of knowledge or unity.

Man is obsessed with certainty because of the fantasy of magical world. Metaphysics could not release itself from this fantasy. Man aims at gaining control over the world. It has been always sought for a perfect system of thought by which the problem of man and his world can be resolved. That is why even philosophers could not get rid of this fantasy and instead of recognition of the negation and the split subject, they have repressed the traumatic "truth" of impossibility of reaching truth and immediate unity. Hegel as the psychoanalyst of philosophy decided to acknowledge the antagonistic nature of man-world relation and, in this way, when he had released himself of metaphysics of immediacy, he brought a thoroughly new philosophy which faced the repressed thoughts over the history of philosophy.

With the dialectical philosophy, both epistemological and ontological questions are suspended, superseded and thrown into a new plane. The actual reality is constituted by an antagonistic process that develops through the unfolding of diverse forms of consciousness, like the transformation of a seed to fruit. For the transition from one stage to the other, Hegel uses the word Aufhebung; a polysemous word that means: abolish, remove, suspend, break, preserve, transform, overcome, raise or sublate.

The German word Aufhebung can signify coping with the unknown and repressed memories better than the word repression. The terrible memory of unifying with mother is repressed while it is not removed completely but simultaneously preserved and sublated. Although every child represses his wishes and desires throughout his growth, her/her future life is entirely a response to this repressed wish. The repressed wish does not leave her/him easily. The repression and dissatisfaction would lead to accumulation of energy. In every dialectical movement, a sort of force is released owing to the conflict of the two sides of struggle. This energy is the source of the entire activities of a man throughout his/her life. In other words, labor, creativity, productivity or even daydreaming or laziness are diverse forms of response to a primary repression.

Furthermore, the repression is in close connection with death owing to its destructiveness and negativity. Negation is an essential part in every stage of the dialectical process that starts from the sense certainty and ends with the absolute knowledge. When an existing formation is negated, its being is totally exposed to nothingness and death until it was elevated to a higher level. A sort of gradual death is experienced through such negative proceeding. Hegel considers the negation and death as a part of his system rather than excluding it, as Freud wants his patients to accept the terrifying and repressed events. Freud has adequately formulated the significance of the death instinct and negativity through the opposition of life and death derives (Eros and Thanatos) in Beyond the Pleasure Principle. Hegel will argue for Eros and attempt to turn the power of negation and death into life derives in order to overcome the fear of death and nothingness of the servant in the struggle for recognition. When the master threatens the servant's life, the servant will try to preserve his life by making the master feel obliged to recognize him because it is important to conquer the fear of death in favour of life ${ }^{1}$.

Another significant point in the mechanism of repression, which is in close connection with the dialectic, is the intersubjectivity or sociality aspect of dialectics and repression. Mother-child-father as well as master-servant relation are inter-subjective. Relations of man-woman and brother-sister, which their sublation is important in transition from the familial life to the civil life, are also happening within a social and inter-subjective framework. Albeit, contrary to the other relations, Hegel does not consider brother-sister relation as a battle or full of desires; a key point in deconstructing Hegel that will be discussed in more detail later on.

The complication of the encounter of the two consciousnesses in dialectic of master-servant reveals previous theories of knowledge that suffer a significant neglect; they have neglected that the subject-object dialectic is preceded by

1- It is worth mentioning that while Derrida and Bataille welcome that Hegel noticed the significance of death and negation, they think that Hegel did not remain faithful to this insight. Derrida, moreover, thinks that Freud did not miss the point when he discussed the death derive, however, the psychoanalytic discourse could not follow the general economy of devotion to death or negativity without reserve and we can conclude that it has confined itself to the restricted economy of analyses and rational discourses. For more details for Derrida and Btaille on Hegel see Derrida's "From restricted to General Economy" in Writing and Difference. 
the subject-subject dialectic. Due to this fact, Hegel has replaced the subject-object theories of knowledge with his theory of self-consciousness in which we are entangled with the other objects as well as other subjects. In this way, we should ask about the sociality of self-consciousness rather than the way we represent the world (Pinkard, 2010, p. 44). It is intriguing that by rejection of theories of representation some new notions in modern philosophy were set forth in Phenomenology of Spirit such as desire, life, fear, death and struggle for recognition that are themes and notions used in psychoanalytical discourse too. According to Hegel "self-consciousness is desire" and "Self-consciousness attains its satisfaction only in another self-consciousness" (Hegel, 2010, p. 158-159). Such statements affirm the psychoanalytical as well as the inter-subjective aspects of Hegelian thought.

The philosopher of spirit analyzes the experience of consciousness and tries to heal the wounds resulted by the gap between man and his community in order to prepare him for Sittlichkeit; the ethical-rational life. Freud, similarly, tries to cure his patients in order to reduce their pain and let them return to the society to accomplish their life derives. The aim of examining the striking similarities between dialectic and repression is to show why Derrida believes in resistance to analysis and how deconstruction diverges from Freud and Hegel.

\section{The Aporia of the Analysis}

Derrida's objections to Freud and Hegel are a part of his criticisms of the phallogocentrism of western thought. Philosophy is logo-centric and psychoanalysis is phallus-centric. These two metaphysical discourses meet at the question of femininity (Antigone) in Hegel's work. They cannot transcend the present context, since both of them seek an origin, meaning and ultimate truth. They pay no attention to the other things. Both, Hegel and Freud, have challenged the metaphysical beliefs of truth but they were not utterly successful in this regard. Derrida has even attacked Lacan because he intended to disclose the concealed meaning of Edgar Allan Poe's "the Purloined Letter" in his psychoanalytical interpretation2.

Deconstruction neither is obsessed with discovering the concealed meaning like hermeneutics nor with the mechanisms that convey meaning as structuralism. It emphasizes the aporetic condition in which meaning is always delayed. Accordingly, as far as Freudian repression and Hegelian Aufhebung are against the metaphysical belief of discovering the concealed meaning Derrida welcomes them and whenever they deviate this, he will criticize them by referring to the abyssal points of their analyses. To maintain that the existing reality is constituted of principles with a determined origin and end is as metaphysical as announcing that there is nothing behind the curtain. We can only speak of openness toward the others that interrogates every principle, origin, end, meaning, ultimate truth or presence, in general, whether theological or ontological.

In his Resistance to Psychoanalysis, Derrida refers to different types of resistance to analysis and conceptualization in psychoanalysis. The resistance that comes from id in connection with the death derive is the most significant one (Howells, 1999, p. 120). Resisting the analysis means to resist attaining original and hidden meanings. Every analysis aims at clarification and demonstration of some basic points through decomposing the subject, dissecting it and describing the mechanisms that govern its structure. Regarding the objectives of an analysis, repression and dialectic are located between the ultimate meaning and the delayed meaning; because on the one hand, they clearly delineate the hidden meanings while, on the other hand, there are insights in their works that accentuates the ambiguity of the subject matter. Such unclear position has the merit of being not dogmatic or metaphysical, however, it lacks a significant insight; neglecting the sequences of such ambiguous situation. The insensitivity of Freud and Hegel to these sequences has made their theories seems metaphysical. Albeit, Derrida does not overlook that, in his Beyond Pleasure Principle, Freud has made an impressive achievement when he set forth the idea of compulsion of repetition that arises from id. This pure repetition is devoid of meaning while connected to the death drive. Now, it should be demonstrated that how Hegel's treatment of the repression has entrapped him, as leading figure in critique of metaphysics, into the metaphysics.

The transition from the divine law (the laws of heart, blood laws of family) to the human beings law (civil laws) is possible by means of children, brother-sister relation precisely. This specific relation, for Hegel, makes the family, as a small community with blood laws, sublate to the higher level of civil society with more complicated laws that are based on rationality rather than blood or divine orders. Briefly, the family is the consequence of mutual recognition of man and woman that leads to sublation of their gap by giving birth to children that are different sexually (son and daughter) but with the same blood. Their relation is without conflict or desire toward each other like other boys and girls relations. Brothers and sisters live in peace and love but contrary to master-servant or father-mother relations they are distanced from

2- See The Post Card: From Socrates to Freud and Beyond, pp. 411-496. 
struggle. In spite of their difference, they are recognizing each other in peace and unity (Hegel, 2010, p. 399). Brothersister relation appears as a preliminary stage of people relations in Sittlichkeit3. After that, "he makes a transition from the divine law, in whose sphere he had lived, to the human law. However, either the sister becomes, or the wife remains, the overseer of the household and the guardian of the divine law" (pp. 400-401). It should be pointed out that Hegel is no longer Freudian in this regard. According to Freud's studies on incest prohibition, the brother-sister relation is not as peaceful as Hegel expressed4. Hence, Derrida concentrates on "family" and brother-sister relation as the Achilles heel of Hegelian system that appears in Hegel's interpretation of Antigone in particular.

Sophocles' Antigone is the story of a woman that defies the ruler's order about her bother. Her brother sentenced to death and his body must be left without funeral rites until it is worn out. Antigone decides to defy the civil law in favour of the family law, because she must preserve the law of heart and blood as a woman. She thus insists that her brother must have a burial ceremony. For Hegel, it is impossible to move to the realm of human law and civil society unless we dismiss the family law. Antigone is the sister that interrupts this transition. When the clash of divine and civil law cannot be sublated, the tragedy will arise. Antigone commits suicide after she was thrown into jail and her fiancée, too, joins her by killing himself. The fear and death thus cast a shadow on the city.

Antigone's debate does a particular part in making distinction between deconstruction, philosophy and psychoanalysis; this is the point by which Hegel, Freud and Derrida simultaneously get very close and diverge as well. Hegel is fascinated with Antigone, according to Derrida, although he apparently reproaches her for rejecting the civil law (Gearhart, 2001, p. 162). How should we conceive this simultaneous hatred and love? Here, with the emergence of an abyss at the very heart of Hegelian system the aporia of analysis emerges. Which abyss and how Hegel is entrapped?

When Hegel tried to treat the repressed problems of philosophy by means of dialectic and negative thinking, he was obviously aware of the significance of death and negativity as the abyss of any philosophical system, however, the problem is more extensive. In other words, philosophy has suffered a more critical problem that even the Hegelian system cannot treat it. Hegel, who brought everything even the most unintelligible and repressed issues in the history of philosophy under cognition, could not disclose a repressed desire within himself that is the incest prohibition. Antigone represents the feminine and the sister. Despite all her self-consciousness and critical thinking, a woman or better to say the truth, for the truth according to Nietzsche disguises as woman, has deceived Hegel. Hegel's ambivalence, a Freudian term that refers to the interdependence of love and hate (Evans, 2006, p. 6), shows that Hegel could not overcome the gap of hate and love. Although many efforts were devoted to reconciliation of the opposites, he failed in the problem of Antigone.

Hegel's ambivalence towards Antigone, the woman and the sister that reminds death and tragedy, made Hegel lose his control over the power of death that he pledged to channel it into life derives. He has ironically relapsed into the abyss of death derives. From a Freudian point of view, the reason for Hegel's sensitivity to Antigone is that brother-sister relation, in contrast to Hegel's conception, is not devoid of desire and tension. It means that Hegel was forced to repress this desire in order to heal some other repressed wishes. This is an aporetic situation.

Hegel is the great inheritor of the enlightenment who argues for better life and Eros against death and destruction. $\mathrm{He}$ is engrossed with the idea of channeling death into creativity and advancement, but Antigone suddenly appears and shows him the other side of the opposition. By mentioning Hegel's simultaneous hate and live, Derrida indeed refers to Hegel's ambivalence concerning "meaning" and "truth", the truth that appears in form of a woman. Antigone does not allow for an easy transition to the civil law through brother-sister relation. Although his healthy attitude regarded this relation as the preliminary stage of the social-ethical life (Sittlichkeit), Hegel has faced a very tough sister who set out to break down his ambitious plans.

As an indigestible element of the Hegelian system, Antigone cautions Hegelian system to pay attention to its lacks; its abysses and others in a quasi-transcendental way. As it was mentioned, the transcendentalism wants to transcend from the present to the other. The intriguing point is that the system cannot exist without this abyss. In other words, this abyss provides, in a sense, the condition of possibility of the Hegelian system and that is why Antigone, as a feminine figure, is "the abyss playing an almost transcendental role" (Derrida, 1986, pp. 151-162).

Antigone represents death derives, femininity, and the repressed element of the system that opposes Eros, masculinity and determined negation. Derrida's reading of Hegel has demonstrated that it is impossible to decide between the oppositions of death/life, the feminine/the masculine, instinct/reason or non-system/system. This indecidability approves the aporia of the analysis. We cannot reduce one to the other; each one is internal to the other (Gearhart, 2001, p. 168).

3- See Kevin Thompson, "Hegelian Dialectic and the Quasi-Transcendental in Glas" in Hegel After Derrida, pp. 245-253.

4- See Freud's "Three Essays on the Theory of Sexuality" in Freud, Complete Works. 
The emergence of an unintelligible element within the philosophy system is the worst nightmare that Hegel may have. Nevertheless, Hegel is not totally unaware of the power of death derives for he mentioned death as the absolute master (Hegel, 2010, p. 170). For Derrida, a sort of resistance, which comes from the "analysis" itself, will oppose any truth-seeker thinking that attempts to disclose the hidden "meaning" by means of "analysis". Therefore, the problem cannot be reduced to dealing with the repression by neglecting the death derive that is characterized by its nihilistic and meaningless repetition. It is an impressive achievement to grasp that repression is always already happening. However, the futile and obscure repetition of the death derive is manifested by Antigone. The death derive brings a futile dialectic to mind that never comes to a synthesis.

\section{Conclusion}

Although psychoanalysis did not exist in Hegel's time, as a field of study, his works did not ignore psychoanalytical ideas and insights. Thus, a comparative study of Freud and Hegel would promise intriguing results ${ }^{5}$. Far beyond comparative studies, Derrida wants to approve his deconstructive claims. By bringing in Kant, Hegel and Freud while arguing for one thinker against the other, he aims at expressing his own views finally. Even though Kant, Hegel and Freud's works have been contaminated by metaphysics, there are unread parts and unresolved antinomies that resist any philosophical or psychoanalytical analysis in their works that can be shown through a rigorous examination. Derrida refers to the quasitranscendental in order to resist the search for hidden truth and meaning whether in determining transcendental principles or the employment of negation force to construct an ethical-rational society. The investigation of the dialectic due to the mechanism of repression and the significance of death derive reveals an abyss within the Hegelian system that turns into its other, the other of the system or the other repressed by the system. Deconstruction tries to open up systems and institutions to other possibilities. Accordingly, it should underscore this aporetic side of the system to resist its totality.

Obviously, we are talking about deconstruction within the metaphysical discourse and deconstruction itself follows the procedure of analysis including decomposing, dissecting, extracting governing regulations, etc. Both deconstruction and psychoanalysis are caught by an aporetic state and unknown destinations, but what makes deconstruction different is showing more sensitivity to such aporetic condition and being more conscious about it while psychoanalysis does not refer to its limitations and its paralysis. Both of them do analysis but while other discourses seek hidden meanings, deconstruction turns away from any origin, principle, meaning or truth. This stems from the new mode of thinking Derrida introduced by his quasi-concept of différance that tries to develop a non-dialectical philosophy.

\section{References}

Billig, Michael. Freudian Repression: Conversation Creating the Unconscious. Cambridge: Cambridge University Press, 2004. Derrida, Jacques. Writing and Difference. Translated by Alan Baas. London and New York: Routledge, 2005.

Derrida, Jacques. Glas. Translated by John P. Leavey, Jr., and Richard Rand. Lincoln: University of Nebraska Press, 1986.

Derrida, Jacques. The Post Card: From Socrates to Freud and Beyond. Translated by Allan Bass. Chicago IL: University of Chicago Press, 1987.

Evans, Dylan. An Introductory Ditionary of Lacanian Psycholanalysis. London \& New York: Routledge, 2006.

Fodor, Nandor and Gaynor, Frank. Freud: Dictionary of Psychoanalysis. New York: Philosophical Library, 1950.

Freud, Sigmund. Compelte Works. Translated by Ivan Smith. Ivan Smith's Website.

Gearhart, Suzanne. "The Remnants of Philosophy: Psychoanalysis after Glas" in Hegel After Derrida. Edited by Stuart Barnett, London \& New York: Routledge, 2001.

Hegel, George F. W. The Phenomenology of Spirit. Translated by Terry Pinkard. Terry Pinkard's Website, 2010.

Howells, Christina. Derrida: Deconstruction from Phenomenology to Ethics. Cmabridge: Polity Press, 1999.

Mills, Jon. The Unconscious Abyss: Hegel's Anticipation of Psychoanalysis. Albany NY: State University of New York, 2002.

Thompson, Kevin. "Hegelian Dialectic and the Quasi-Transcendental in Glas" in Hegel After Derrida. Edited by Stuart Barnett, London and New York: Routledge, 2001.

5. For comparative studies of Hegel and Freud, or psychoanalysis in general, see The Unconscious Abyss: Hegel's Anticipation of Psychoanalysis. 